\title{
COMPARATIVE ANALYSIS OF THREE SOLUTIONS FOR TORSION REDUCTION IN CASE OF FLEXIBLE TUBE CONCRETE STRUCTURES
}

\author{
Marius Florin Botiş ${ }^{1}$ \\ Imre Lajos ${ }^{2}$
}

UDK: 539.414

DOI: 10.14415/konferencijaGFS2019.023

Summary: In the present paper, the authors propose to determine the optimal torsion reduction solution for flexible tube structures by modal analysis. In the paper are proposed three solutions for analysis: structures with central tube and perimetral walls on sides, structures with central tube structures and perimetral walls on the corner and structures with central tube with structural walls type stairs positioned inside the structure.

Keywords: Lateral stiffness, general torsion at concrete structures, modal analysis, comparative study, structural conformation.

\section{INTRODUCTION}

From Joseph Monier to Eugène Freisinet and to the present day reinforced concrete captured the attention of engineers due to the several possibilities and advantages what this composite material can offer. In the last two century we could observe a demographical rise and the limitations of spatial territory in which human settlements can expand and develop. The rational solution is vertical expansion, to design structures with limited base and height number of stories. This solution tend to induce difficulties in structural design, therefore a correct gravitational and seismic structural design is required. The main characteristic of flexible tube structures is the spatial collaboration between rigid concrete walls, central core with flexible frame structures. This spatial collaboration is thanks to the rigid diaphragm hypothesis of the plates and the ductility property.

\section{DESCRIPTION OF THE STRUCTURE}

In the hereby example (figure 1) we study a flexible tube structure which has two axes of symmetry. The total length of the structure is $10,6[\mathrm{~m}]$, and height $6[\mathrm{~m}]$, meaning $\mathrm{P}+1 \mathrm{~F}$. The calculus and the results are not affected by the height, the only difference will be the

\footnotetext{
${ }^{1}$ Marius Florin Botiş. assoc. prof., Univerity "Transilvania" of Braşov, Faculty of Civil Engineering, Romania

${ }^{2}$ Imre Lajos., student, Univerity "Transilvania" of Braşov, Faculty of Civil Engineering, Romania, e - mail: lajos.imre@student.unitbv.ro
} 
Савремена достигнућа у грађевинарству 23-24. април 2019. Суботица, СРБИЈА

amplification off the displacements but the general torsion will appear, no matter the height of the structure.
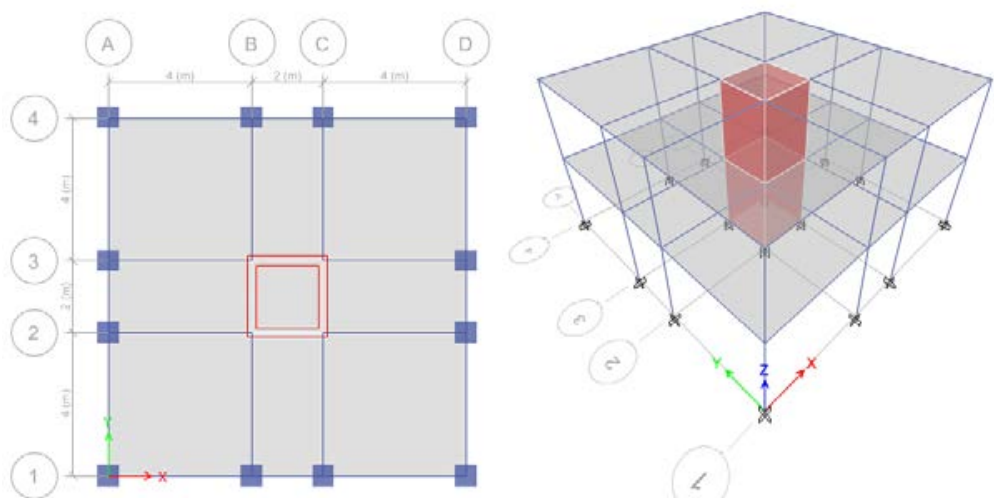

Figure 1. Flexible tube structure in plan and elevation

The columns are $600[\mathrm{~mm}]$ x $600[\mathrm{~mm}]$, the beams $300[\mathrm{~mm}]$ x $600[\mathrm{~mm}]$, the slab section is 150 [mm], the structural walls are 250 [mm], and also the main core and the addition walls introduced to reduce the effect of torsion. The material we use, the grade of concrete C20/25 and the grade of steel PC52. The main loads and earthquake date are presented in table1.

Table 1. Main loads and earthquake date.

\begin{tabular}{|c|c|}
\hline Super dead load & $1,5\left[\mathrm{kN} / \mathrm{m}^{2}\right]$ \\
\hline Live load & $3\left[\mathrm{kN} / \mathrm{m}^{2}\right]$ \\
\hline Roof load & $5\left[\mathrm{kN} / \mathrm{m}^{2}\right]$ \\
\hline Loads from snow, roof & $1,6\left[\mathrm{kN} / \mathrm{m}^{2}\right]$ \\
\hline Location, Country & Braşov, România \\
\hline $\mathrm{a}_{\mathrm{g}} / \mathrm{g}$ & 0,2 \\
\hline $\mathrm{T}_{\mathrm{C}}$ & $0,7[\mathrm{~s}]$ \\
\hline $\mathrm{T}_{\mathrm{B}}$ & $0,14[\mathrm{~s}]$ \\
\hline $\mathrm{T}_{\mathrm{D}}$ & $3,00[\mathrm{~s}]$ \\
\hline Importance factor & 1,00 \\
\hline Framing type & D.C.H. \\
\hline Behavior factor & 3,00 \\
\hline Base shear coefficient, $\mathrm{c}$ & 0,20 \\
\hline Damping & $5[\%]$ \\
\hline
\end{tabular}

The columns are oriented after 4 axes, and the reinforced concrete walls are positioned in the center, due to the fact that the study is about a flexible tube structure. The main loads corresponds to the prescriptions of CR1-1-1 and CR1-1-3. 
Contemporary achievements in civil engineering 23-24. April 2019. Subotica, SERBIA

\section{MODAL ANALYSIS AND THEORETICAL CONCEPTS.}

As mentioned in paragraph 2 the acceleration-induced inertia forces by earthquake can generate unfavorable behavior of the structure. At the point of seismic conformation we need to take in consideration three aspects. The first is related to the center off mass and the center of stiffness. The center off mass is a position defined as the average position off all parts of the system, weighted according to their mass. ${ }^{[1]}$ The inertial forces will act in this point and there are reduced to the center off stiffness. The main purpose is to reduce to minimum this distance to avoid general torsion in the I mode of vibration. The second condition is to ensure that the principle direction of the inertial forces is identical with one geometric ax of the structure. In this way we ensure that the columns and beams are bended not stretched. If we stop here and consider that the problem of ensuring a proper behavior of the structure we can find ourselves in the present situation. The center off mass and the center off stiffness are in the same position and the principle directions are the same with the geometric axes $\mathrm{x}$ and $\mathrm{y}$, due to structural symmetry in plan and elevation. If we take an example in plan a structure has three mechanical characteristics relative to the three degrees of freedom. This can be expressed by three parameter two of forces and a moment. The hierarchy of these three elements will determine the main behavior of the structure. A very good example to forecast the present situation is by using sensibility at torsion. In the present situation we can see that in the I mode of vibration appears torsion, due to the fact of flexible tube. The modal analysis is perfomed with Etabs 2016. The modal analysis results are presented in table 2 .

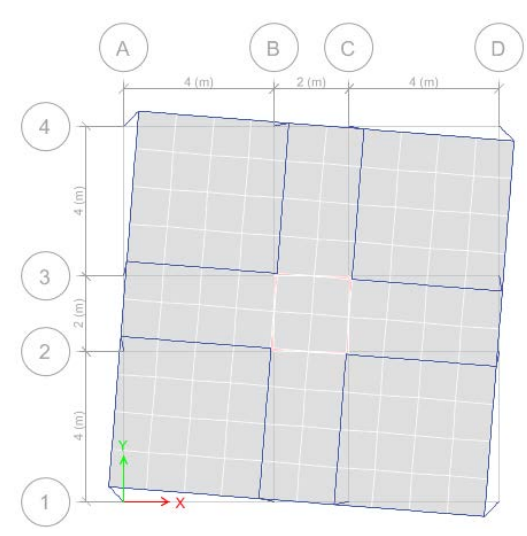

Figure 2. Deformed shape of the main structure

Table 2. Modal participating mass ratios of the main structure.

\begin{tabular}{|c|c|c|c|c|c|c|c|c|}
\hline Case & \multirow{2}{*}{ Mode } & Period & UX & UY & RZ & $\begin{array}{c}\text { Sum } \\
\text { UX }\end{array}$ & Sum UY & Sum RZ \\
\cline { 3 - 8 } Modal & 1 & 0,118 & 0 & 0 & 0,879 & 0 & 0 & 0,879 \\
\hline Modal & 2 & 0,101 & 0,472 & 0,354 & 0 & 0,472 & 0,3542 & 0,879 \\
\hline Modal & 3 & 0,101 & 0,354 & 0,472 & 0 & 0,826 & 0,8257 & 0,879 \\
\hline
\end{tabular}


Савремена достигнућа у грађевинарству 23-24. април 2019. Суботица, СРБИЈА

\section{CASE STUDY}

\subsection{Structure with central tube and perimetral walls on sides.}

In this case we displayed two walls relative to two opposite corners, the main structure and the deformed shape in the I mode of vibration in figure 3 . The length off the wall is 4 [m], afterwards we ran the modal analyses and obtained the results in table 3.

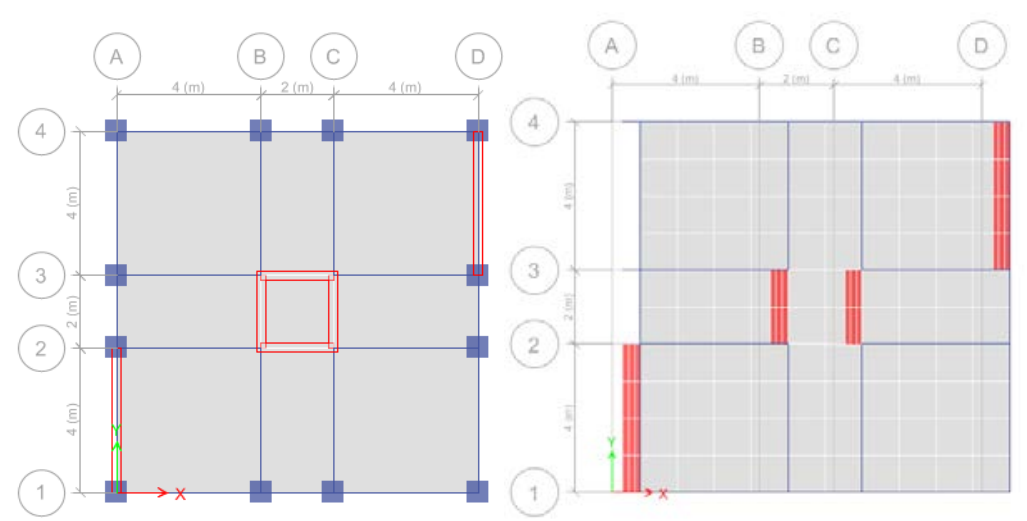

Figure 3. Flexible tube structure with secondary walls „, before” and „after” the analysis

Table 3. Modal participating mass ratios of the case 1.

\begin{tabular}{|c|c|c|c|c|c|c|c|c|}
\hline Case & Mode & Period & \multirow{2}{*}{ UX } & UY & RZ & $\begin{array}{c}\text { Sum } \\
\text { UX }\end{array}$ & Sum UY & Sum RZ \\
\cline { 3 - 7 } Modal & 1 & 0,103 & 0,814 & 0 & 0 & 0,8142 & 0 & 0 \\
\hline Modal & 2 & 0,051 & 0 & 0,840 & 0 & 0,8142 & 0,84 & 0 \\
\hline Modal & 3 & 0,049 & 0 & 0 & 0,855 & 0,8142 & 0,84 & 0,855 \\
\hline
\end{tabular}

We can see that this is an ideal situation in which in the I and II mode of vibration do not appear torsion, only in the third one. The values in the I mode of vibration indicates that we have translation on the geometrical $x$ direction. In this way we reduced to zero the effect of torsion and the structure is capable of forming a favorable plastic mechanism to dissipate energy induced by earthquakes. 
Contemporary achievements in civil engineering 23-24. April 2019. Subotica, SERBIA

\subsection{Structure with central tube structures and perimetral walls on the corner.}

In this case we displayed two walls relative to two opposite corners in both directions, in every direction the wall has 2 [m]. If we make an equivalent form we obtain a length of the wall of 2,84 [m], at an angle off $45^{\circ}$ relative from axe $\mathrm{x}$. The structure and the deformed shape in the I mode of vibration are presented in figure 4. After the modal analyses we obtained the results in table 4 .
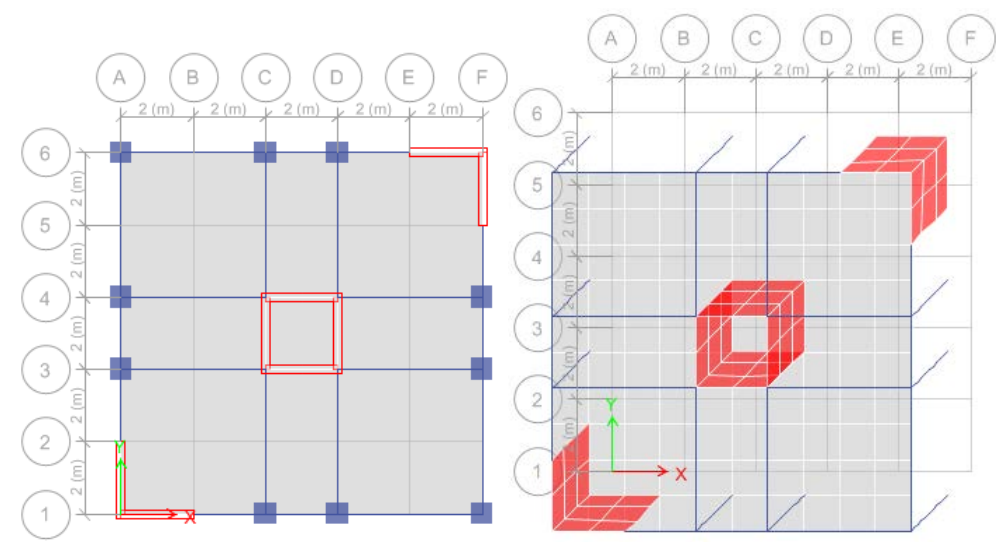

Figure 4. Flexible tube structure with secondary walls „, before” and „after” the analysis

Table 4. Modal participating mass ratios of the case 2.

\begin{tabular}{|c|c|c|c|c|c|c|c|c|}
\hline Case & Mode & Period & UX & UY & RZ & $\begin{array}{c}\text { Sum } \\
\text { UX }\end{array}$ & Sum UY & Sum RZ \\
\hline Modal & 1 & 0,09 & 0,402 & 0,407 & 0 & 0,4022 & 0,4072 & 0 \\
\hline Modal & 2 & 0,076 & 0,412 & 0,407 & 0 & 0,8139 & 0,8142 & 0 \\
\hline Modal & 3 & 0,062 & 0 & 0 & 0,828 & 0,8139 & 0,8142 & 0,8283 \\
\hline
\end{tabular}

We can see that in this case we reduced the effect of torsion but we have displacement on both geometric directions. This situation can be managed by shorting one and increasing the other. The final ideal result is case 1 . Another solution is to add other structural elements or to modify the geometric form of some columns after a determined direction.

\subsection{Structure with central tube with structural walls type stairs positioned inside the structure.}

In this case we displayed two walls between the central tube and the external line of columns, which act as supports for staircases. There are positioned relative perpendicular 
Савремена достигнућа у грађевинарству 23-24. април 2019. Суботица, СРБИЈА

with the length of the wall of 2,84 [m], at an angle off $45^{\circ}$ relative from axe $\mathrm{x}$. The structure and the deformed shape in the I mode of vibration in figure 5 . After the modal analyses we obtaine the results in table 5.1.

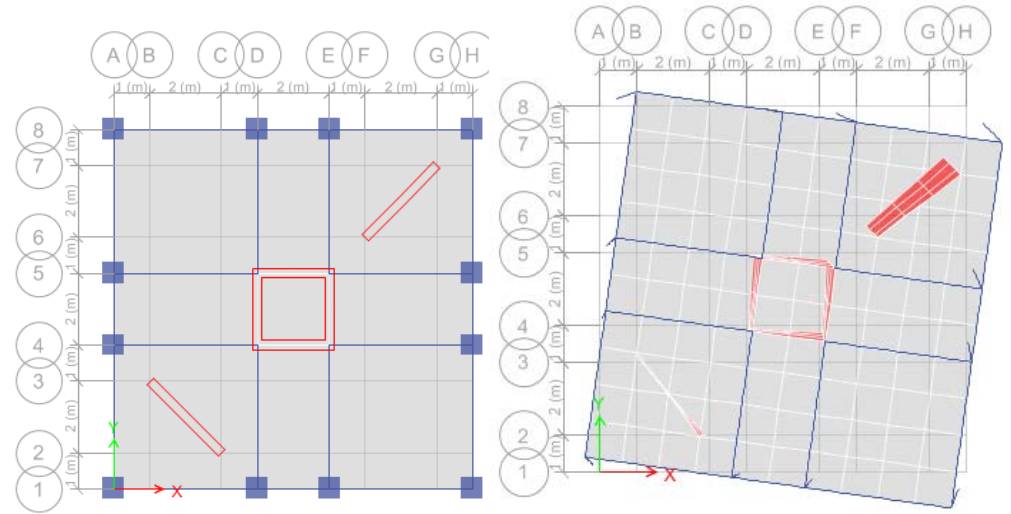

Figure 5. Flexible tube structure with secondary walls „, before” and „after” the analysis

Table 5.1. Modal participating mass ratios of the case 3.a.

\begin{tabular}{|c|c|c|c|c|c|c|c|c|}
\hline Case & \multirow{2}{*}{ Mode } & Period & \multirow{2}{*}{ UX } & UY & RZ & $\begin{array}{c}\text { Sum } \\
\text { UX }\end{array}$ & $\begin{array}{c}\text { Sum } \\
\text { UY }\end{array}$ & $\begin{array}{c}\text { Sum } \\
\text { RZ }\end{array}$ \\
\cline { 3 - 8 } Modal & 1 & 0,114 & 0,1273 & 0,1279 & 0,6154 & 0,1273 & 0,1279 & 0,6154 \\
\hline Modal & 2 & 0,084 & 0,4128 & 0,4168 & 0 & 0,5402 & 0,5447 & 0,6154 \\
\hline Modal & 3 & 0,079 & 0,2872 & 0,2828 & 0,2605 & 0,8273 & 0,8275 & 0,8759 \\
\hline
\end{tabular}

We can see that in this case the torsion appears also in the first mode of vibration. If we change the direction of a wall we obtain situation with the deformed shape in figure 6 and the modal analysis results presented in table 5.2.
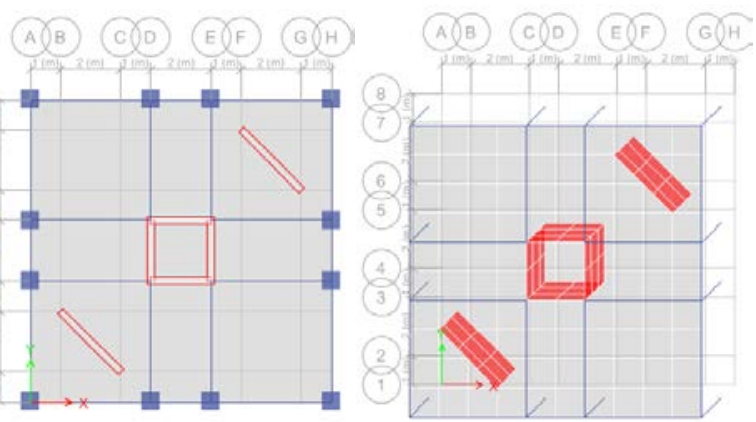

Figure 6. Flexible tube structure with secondary walls „, before” and „after” the analysis 
Contemporary achievements in civil engineering 23-24. April 2019. Subotica, SERBIA

Table 5.2. Modal participating mass ratios of the case $3 . b$

\begin{tabular}{|c|c|c|c|c|c|c|c|c|}
\hline Case & \multirow{2}{*}{ Mode } & Period & \multirow{2}{*}{ UX } & UY & RZ & $\begin{array}{c}\text { Sum } \\
\text { UX }\end{array}$ & Sum UY & $\begin{array}{c}\text { Sum } \\
\text { RZ }\end{array}$ \\
\cline { 3 - 9 } Modal & 1 & 0,101 & 0,4139 & 0,4153 & 0 & 0,4139 & 0,4153 & 0 \\
\hline Modal & 2 & 0,083 & 0 & 0 & 0,849 & 0,4139 & 0,4153 & 0,8487 \\
\hline Modal & 3 & 0,075 & 0,4091 & 0,4079 & 0 & 0,823 & 0,8231 & 0,8487 \\
\hline
\end{tabular}

We can see that if we rotate one element it do not reduce torsion in the I mode of vibration. General torsion will appear inevitably.

\section{CONCLUSIONS}

The main conclusion is that with increasing the stiffness of one side of the structure it is able to reduce the effect of torsion. The greater the distance between the center off stiffness and the center of the structural element the stiffness coefficient will increase reducing the angle of distortion relative to the center off stiffness.

This constructive solution is implemented in the case of height structures, because the frame structures become too flexible, displacements and degradations increase, and the structures with reinforced concrete walls have great mass.

For the three examples treated the authors tried to present the importance of seismic conformation of the structure to ensure a favorable energy dissipating mechanism, and to forecast the behavior of the structure for lateral, inertial forces.

\section{REFERENCES}

[1] B. G. Naresh Kumar, Punith N., Bhyrav Raj B., Arpitha T. P.: Assessment of Location of Center of Mass and Center of Stiffness for Different Setback Buildings.

[2] P 100-1 / 2013

[3] Computers and Structures, Inc. (C.S.I.), ETABS 2016 Software, V16.2; 2017 